\title{
Seroprevalence of Viral Hepatitis in Riverine Communities from the Western Region of the Brazilian Amazon Basin
}

\author{
VS de Paula $/{ }^{+}$, ME Arruda*, CLVitral $/{ }^{* *}$, AMC Gaspar
}

\begin{abstract}
Departamento de Virologia, Instituto Oswaldo Cruz-Fiocruz, Av. Brasil 4365, 21045-900 Rio de Janeiro, RJ, Brasil *Departamento de Imunologia, Centro de Pesquisas Aggeu Magalhães-Fiocruz, Recife, PE, Brasil **Departamento de Microbiologia e Parasitologia, Instituto Biomédico, Universidade Federal Fluminense, Niterói, RJ, Brasil
\end{abstract}

The western region of the Brazilian Amazon Basin has long been shown to be a highly endemic area for hepatitis $B$ and hepatitis $D$ viruses. Data concerning the prevalence of hepatitis $C$ and $E$ viruses in this region are still scarce. In this study we investigated the presence of hepatitis $A, B, C, D$ and $E$ viruses infection in communities that live along the Purus and Acre rivers in the states of Acre and Amazonas within the Amazon Basin. A total of 349 blood samples were collected and tested for hepatitis A-E serological markers (antibodies and/or antigens) using commercial enzyme linked immunosorbent assays. Anti-HCV positive sera were further assayed by an immunoblot. HBsAg positive sera were subtyped by immunodifusion. The overall prevalence for hepatitis $A, B, C$, and $E$ were $93.7 \%, 66.1 \%$, $1.7 \%$, and $4 \%$, respectively. A very high prevalence of delta hepatitis (66.6\%) was found among $\mathrm{HBs} \mathrm{Ag}$ positive subjects. Hepatitis $A, B$ and $D$ viruses were shown to be largely disseminated in this population, while hepatitis $C$ and $E$ viruses infection presented low prevalence rates in this region. The analysis of risk factors for $H B V$ infection demonstrated that transmission was closely associated with sexual activity.

Key words: hepatitis A - hepatitis B - hepatitis C - hepatitis D - hepatitis E - Amazon Basin - Brazil

Viral hepatitis is considered a worldwide public health problem, representing a significant cause of morbidity and mortality. Most acute and/or chronic hepatitis cases result from infection with one of the hepatitis viruses, named from A to E. In Brazil different patterns of hepatitis viruses distribution are found throughout the country. Hepatitis A virus (HAV) infection is endemic especially among low socioeconomic populations, although a decrease in its prevalence has been observed recently in areas where sanitary conditions have been improving (Pinho et al. 1998, Vitral et al. 1998a,b). Hepatitis $\mathrm{E}$ virus (HEV) is considered a major etiological agent of enterically-transmitted viral hepatitis in several developing countries. In Brazil, the seropositivity for anti-HEV antibodies has been observed in some Brazilian population groups, but the occurrence of acute hepatitis E cases has not been notified (Pang et al. 1995, Souto et al. 1997) except in one report

\footnotetext{
This study was supported by Colab, CNPq and Faperj. +Corresponding author. Fax: +55-21-2270.6397. E-mail: vdepaula@gene.dbbm.fiocruz.br

Received 30 January 2001

Accepted 27 June 2001
}

from the northern part of the country (Parana et al. 1997). Prevalence rates of hepatitis B virus (HBV) infection increase from South to North of the country. The Amazon region has one of the highest rates of HBV carriers in the world (5-20\%), affecting mainly children and young adults (Bensabath et al.1987b, Fonseca et al. 1988, Soares et al. 1994, Souto et al. 1998). In fact, hepatitis of all kinds assumes alarming proportions in Amazônia, where it is a major cause of morbidity and mortality. Hepatitis mortality in this region is 5-10 times higher than averages for the rest of the hemisphere (Fay et al.1985, Bensabath et al. 1987b). Hepatitis delta virus (HDV) is also highly endemic in the State of Amazonas (Bensabath et al. 1987a, Pereira et al. 1993), with rates varying from $3.9 \%$ to $34.4 \%$ among HBsAg carriers. In this region, HDV infection is also common among acute hepatitis B cases (29\%) and fulminant hepatitis cases (74\%), as observed in the Boca do Acre municipality (Bensabath et al. 1987a). Most of the knowledge about hepatitis C virus $(\mathrm{HCV})$ infection in Brazil has been acquired from seroprevalence studies carried out in blood donors and hemodialysis patients from large cities. Few studies have addressed the HCV prevalence in the Amazon region, showing prevalence rates ranging from $1.4 \%$ among Amazonian indian tribes to $3.6 \%$ among immigrants living in the region (Soares et al. 1994, Souto et al.1996). Considering 
that the Amazon region is highly endemic for HBV infection and that HBV and HCV share similar modes of transmission, the investigation of seroprevalence rates for HCV infection has public health importance.

At the beginning of 1997, a team of researchers from different areas (historians, anthropologists, biologists and medical doctors), spent 46 days along the Acre and Purus rivers in the western Amazon collecting information regarding the health conditions of some endemic diseases previously described by Carlos Chagas in 1813 (dos Santos et al. 1996). Here we report results of an investigation of hepatitis A-E viruses infection based on serological markers in blood samples from individuals living in communities along these rivers.

\section{MATERIALS AND METHODS}

Description of the region and population - The region under study encompasses the headwaters Acre and Purus rivers as well as some of its tributaries located in the States of Acre and Amazonas. With the exception of six large towns, the other 17 riverside villages are remnants of old rubber plantations. Only a few of these sites were accessible by vehicle; most of them could be reached only by boat or canoe. The population density along the river was very scattered and most of the inhabitants lived in sagopalm leaf shelters located at least a few kilometers from other human settlements. The villages are composed of farmers and their principal cash crop was manioc and Brazil nuts. Almost all the villages had shorelines polluted by animal and human waste. In addition, cleaning of dishes and discard of vegetable matter and dirty water were processed in a kitchen-like compartment located at the back of the houses. At those places, animals gathered to eat the wastes and wallow in the water. Shoeless children regularly passed through and bathed in the river water as did adults. Water for drinking and cooking was obtained along the shoreline or from the middle of the river. Rarely did a settlement have its own well. All houses lacked a sewage system, providing a great potential for fecal contamination of the water supply. Some settlements had chickens, pigs and occasional cows. Fishing appeared to be mostly for personal consumption. Some riverine communities had diesel engines for electricity depending on the size of the settlement.

Collection of blood samples and interview The medical team examined 349 individuals, 53.2\% males, aged between 3 to 73 years with a mean age of 19.4. Blood samples were drawn from each individual after previous consent and a questionnaire was administered in order to evaluate possible risk factors: previous history of surgery, blood transfu- sion, tattooing, intravenous drug use, contact with hepatitis virus infected family members, sexual activity, use of condom, number of sexual partners, history of sexually-transmitted diseases and sharing of personal objects in the household.

Serological tests - Serum samples were tested for total antibody to HAV (anti-HAV), IgG antibody to HEV (IgG anti-HEV), HBV surface antigen (HBsAg), antibody to $\mathrm{HBV}$ core antigen (anti-HBc) and antibody to HCV (anti-HCV). All HBsAg reactive subjects were tested for antibody to HDV antigen (anti-Delta) and HBV subtyped. Anti-HAV was determined using a competitive "in-house" EIA (Vitral et al. 1991). HBsAg subtyping was carried out occording the method described by Gaspar and Yoshida (1987). The remaining serological markers were measured by commercial EIAs (Abbott Laboratories and Organon Teknika, Boxtel, The Netherlands). Anti-HCV EIA positive serum samples were tested again by a third generation immunoblot assay (Organon Teknika, Boxtel, The Netherlands).

Statistical analysis - The univariated analysis was determined using Yates correction, odds ratios, $\mathrm{P}$ value and $95 \%$ confidence intervals $(95 \%$ $\mathrm{CI}$ ) in the EPI-6 program (CDC, Atlanta, USA). Differences were regarded as significant when $\mathrm{p} \leq 0.05$.

\section{RESULTS}

Table I shows the age-specific prevalence of enterically-transmitted hepatitis viruses (HAV and HEV). A clear difference between levels of antiHAV and IgG anti-HEV seropositivity was observed. HAV infection was almost universal in this population. By the age of $10,90.9 \%$ of the children had seroconverted to HAV. On the contrary, the seroprevalence of HEV infection was very infrequent in all age groups. The overall $\mathrm{IgG}$ anti-HEV prevalence was $4 \%$.

\section{TABLE I}

Serological prevalence of enterically-transmitted hepatitis virus (HAV and $\mathrm{HEV}$ ) in riverine communities from the western region of the Brazilian Amazon

\begin{tabular}{lrccccc}
\hline & & \multicolumn{2}{c}{ Anti-HAV } & & \multicolumn{2}{c}{ IgG anti-HEV } \\
\cline { 7 - 7 } \cline { 6 - 7 } Age intervals & $\mathrm{n}$ & Positive & $\%$ & & Positive & $\%$ \\
\hline $0-10$ & 22 & 20 & 90.9 & & 9.1 \\
$11-20$ & 72 & 67 & 93 & & 2 & 2.8 \\
$21-30$ & 89 & 83 & 93.3 & & 5 & 5.6 \\
$31-40$ & 55 & 52 & 94.5 & & 3 & 5.4 \\
$41-50$ & 51 & 48 & 94.1 & & 1 & 2 \\
$>51$ & 60 & 57 & 95 & & 1 & 1.7 \\
\hline Total & 349 & 327 & 93.7 & & 14 & 4 \\
\hline
\end{tabular}


Table II shows the age-specific prevalence of parenterally-transmitted hepatitis viruses (HBV, $\mathrm{HCV}$ and HDV). There was a strong trend for increasing HBV infection rate with increasing age. High rates of $\mathrm{HBV}$ infection (positivity for anti-HBc) were recorded since the first decade of life (27.3\%). The overall prevalence of anti-HBc was $66.2 \%$. A total of $18(5.2 \%)$ individuals were positive for HBsAg, among those $12(66.7 \%)$ were also reactive against anti-Delta. Six sera (1.7\%) were positive for anti-HCV by EIA and were confirmed by immunoblot. The age-specific prevalence of HCV antibodies slightly increased with age, with the highest prevalence at the 21-30 year age group.

HBV subtypes found in $10 \mathrm{HBsAg}$ carriers subjects were adw2 (4/10), adw4 (2/10), ayw3 (2/10) and ayw2 (2/10); eight samples could be not subtyped.

Tables I and II show the global pattern of the prevalence of both enterically and parenterally transmitted hepatitis viruses serological markers of infection according to age in this population. A very higher frequency of HAV and HBV infection in comparison with other hepatitis viruses could be observed.

Univariated analysis indicated that the prevalence of HBV infection was significantly higher in individuals who were sexually active $(\mathrm{p}<0.05)$, but not with those with multiple sexual partners (Table III). We did not detect any statistical association among HBV infection related to parenteral or nonparenteral exposure (blood transfusion, surgery, sharing objects in the household and contact with family members with hepatitis). Factors such as intravenous drug use, tattoing, use of condom and history of sexually-transmitted diseases were seldom mentioned by the interviewed people, thus precluding statistical analysis (data not shown). The small seropositivity for HCV and HEV also prevented statistical analysis of risk factors of infection.

\section{DISCUSSION}

Hepatitis A, B and D viruses infection were shown to be endemic among the communities that live along the Purus and Acre rivers in the western Brazilian Amazon. This community-based survey showed $93.7 \%$ and $66.2 \%$ prevalences of anti-HAV and anti-HBc, respectively. Eighteen (5.2\%) individuals were positive for $\mathrm{HBsAg}$, among those $66.7 \%$ were found to be anti-Delta positive. Our results are consistent with other studies that showed that HAV, HBV and HDV are widespread in the Amazon jungle (Arboleta et al. 1995, Azevedo et al. 1996, Coimbra Junior et al. 1996).

The high anti-HAV prevalence $(93.7 \%)$, could be clearly correlated with the local poor sanitary conditions. This endemicity pattern was not evidenced for HEV infection, another water-borne hepatitis virus also prevalent in areas without sanitary facilities. In fact, this population presented a low prevalence of IgG anti-HEV (4\%), an expected rate for non-endemic areas. As already discussed by several authors, detection of anti-HEV in subjects that live in non-endemic areas may be due to cross reactions with other pathogenic organism or serological tests non-specificity (Skidmore 1997). The detection of anti-HEV antibodies in individuals living in non-endemic areas for HEV infection has also led to the hypothesis of the existence of an animal reservoir for HEV. There is strong evidence that HEV is a zoonotic virus that circulates among different animal species including humans. Occasionally, HEV could infect humans through direct contact with domestic or farm animals or with contaminated water supplies (Meng 2000). In this population, some individuals raised domestic animals, but we could not establish a correlation between this factor and the antiHEV seropositivity. Because there were no blood samples available for these animals to be tested for anti-HEV antibodies.

\section{TABLE II}

Serological prevalence of parenterally-transmitted hepatitis virus (HBV, HCV and HDV) in riverine communities from the western region of the Brazilian Amazon

\begin{tabular}{|c|c|c|c|c|c|c|c|c|c|}
\hline \multirow[b]{2}{*}{ Age intervals } & \multirow[b]{2}{*}{$\mathrm{n}$} & \multicolumn{2}{|c|}{ Anti-HBc } & \multicolumn{2}{|c|}{$\mathrm{HBsAg}$} & \multicolumn{2}{|c|}{ Anti-Delta $^{a}$} & \multicolumn{2}{|c|}{ Anti-HCV } \\
\hline & & Positive & $\%$ & Positive & $\%$ & Positive & $\%$ & Positive & $\%$ \\
\hline $0-10$ & 22 & 6 & 27.3 & 1 & 4.5 & 1 & 100 & 0 & 0 \\
\hline $11-20$ & 72 & 36 & 50 & 7 & 9.7 & 4 & 57.1 & 1 & 1.4 \\
\hline $21-30$ & 89 & 63 & 70.8 & 8 & 9 & 5 & 62.5 & 4 & 4.5 \\
\hline $31-40$ & 55 & 42 & 76.4 & 1 & 1.8 & 1 & 100 & 0 & 0 \\
\hline $41-50$ & 51 & 41 & 80.4 & 0 & 0 & 0 & 0 & 0 & 0 \\
\hline$>51$ & 60 & 43 & 71.7 & 1 & 1.7 & 1 & 100 & 1 & 1.7 \\
\hline Total & 349 & 231 & 66.2 & 18 & 5.2 & 12 & 66.7 & 6 & 1.7 \\
\hline
\end{tabular}

$a$ : prevalence of anti-Delta in HBsAg positive individuals 
TABLE III

Analysis of risk factors for $\mathrm{HBV}$ infection according to anti-HBc prevalence among individuals living at riverine communities from the western Amazon Basin

\begin{tabular}{|c|c|c|c|c|c|}
\hline \multirow[b]{2}{*}{$\underline{\text { Risk factors }}$} & \multirow[b]{2}{*}{$\mathrm{n}^{c}$} & \multicolumn{2}{|c|}{ Anti-HBc positive } & \multirow[b]{2}{*}{$\mathrm{p}^{d}$} & \multirow[b]{2}{*}{ OR (CI 95\%) } \\
\hline & & $\mathrm{n}$ & $(\%)$ & & \\
\hline \multicolumn{6}{|c|}{ Contact with hepatitis $a$} \\
\hline Yes & 116 & 83 & 71.5 & 0.81 & $1.12(0.6-2.0)$ \\
\hline No & 104 & 72 & 69.2 & & \\
\hline \multicolumn{6}{|c|}{ Objects of common use $b$} \\
\hline Yes & 193 & 135 & 70 & 0.82 & $0.81(0.29-2.1)$ \\
\hline No & 27 & 20 & 74.1 & & \\
\hline \multicolumn{6}{|c|}{ Blood transfusion } \\
\hline Yes & 15 & 12 & 80 & 0.58 & $1.73(0.43-8.0)$ \\
\hline No & 205 & 143 & 69.8 & & \\
\hline \multicolumn{6}{|l|}{ Surgery } \\
\hline Yes & 43 & 32 & 74.4 & 0.65 & $1.28(0.57-2.9)$ \\
\hline No & 177 & 123 & 69.5 & & \\
\hline \multicolumn{6}{|c|}{ Sexual activity } \\
\hline Yes & 124 & 98 & 79 & 0.00 & $2.58(1.37-4.8)$ \\
\hline No & 96 & 57 & 59.4 & & \\
\hline \multicolumn{6}{|c|}{ Multiple sexual partners } \\
\hline Yes & 6 & 5 & 83.3 & 0.80 & $1.34(0.14-31.8)$ \\
\hline No & 118 & 93 & 78.8 & & \\
\hline
\end{tabular}

$a$ : occurrence of hepatitis cases in the family; $b$ : sharing of personal objects in the household: razor blades, scissors, tooth-brushes and beds; $c$ : total do not add up to 349 because of missing values; $d$ : statistically significant when $\mathrm{p} \leq 0.05$

Different data on HBV prevalence are reported for several Amazon regions, which may suggest an irregular geographical distribution of the infection. Based on the world endemicity categorization of HBV infection (Margolis et al. 1991), the HBsAg prevalence of $5.2 \%$ characterizes the Purus and Acre rivers as an area of high prevalence of $\mathrm{HBV}$ infection. The rates of HBV prevalence observed in this region were not different from those reported for the western part of the Amazon Basin, which has the highest HBV infection prevalence in South America (Fay 1990, Arboleta et al. 1995). The prevalence of anti-HBc was already high (27.3\%) in the youngest age group (0-10 years) and then sharply increased to $50 \%$ and $70.8 \%$ at the $11-20$ and $21-30$ age groups, respectively. This fact suggests that although a considerable proportion of HBV infections in this population is acquire in the early childhood, probably as a result of vertical transmission, most of the remaining infections seemed to be contracted horizontally or sexually from HBV infected subjects. This is in agreement with data from HBV endemic regions, where mother-to-infant transmission does not account for at least $50 \%$ of infections in children and adolescents, and horizontal transmission, i.e. child-to-child transmission is equally important (Dusheiko 1997). Some risk factors related to HBV horizontal transmission were evaluated, such as sharing of personal objects in the household and contact with HBV infected family members, but they were not statistically associated with HBV infection. However, other risk factors could be involved in the horizontal transmission of HBV. Martinson and et al. (1998) described some situations that could enhance the probability of HBV transmission, including sharing gum or candies, biting fingernails, being bitten by a carrier or scratching a carrier's back.

Parenteral risk factors of HBV transmission such as the use of intravenous drugs $(0 / 220)$, previous history of surgeries $(43 / 220,19.5 \%)$ and blood transfusion $(15 / 220,6.8 \%)$ were seldom referred by individuals. In fact, none of these factors was significanty associated with HBV transmission. The only risk factor associated with the seropositivity for HBV markers was sexual activity. Most subjects did not report the use of condoms, which turns sexual activity an important risk factor.

The major HBsAg subtypes found (adw4, adw2) were in accordance with those reported by Gaspar and Yoshida (1987) from the North of Brazil and other seroprevalence studies carried out at the Amazon region (Souto et al.1998).

HDV is known to increase the severity of acute and chronic hepatitis B. Moreover, HDV infection in HBV carriers has been associated with an un- 
usual type of fulminant hepatitis in the Amazon Basin known as Labrea hepatitis (Soares et al. 1994, Casey et al. 1996). The impact of HDV infection should be taken into consideration in the communities that were evaluated in this study, due to the very high prevalence found for this virus. Surprisingly, the proportion of HBV carriers with antibody to hepatitis delta virus (66.7\%) was much higher than other indexes reported from the Amazon region, which may vary from $0 \%$ to $34.4 \%$ (Fonseca et al. 1988, Soares et al. 1994, Arboleda et al. 1995, Azevedo et al. 1996), and even higher than those described in southern Italy (Piccinino \& Sagnelli 1991). In this study, HDV infected subjects did not belong to any recognized high risk group such as drug addicts, homosexuals or hemophiliacs. Most of individuals were native from that region, which suggests that infection with both HBV and HDV occurred inside the Purus and Acre rivers communities.

Previous studies showed anti-HCV prevalence rates ranging from $0 \%$ to $3.6 \%$ in the Brazilian Amazon (Souto et al. 1996, 1999). This study gives the first data on the anti-HCV prevalence in the western Amazon, which presented a low endemicity of HCV infection (1.7\%). Although the small seropositivity for HCV has prevented the evaluation of risk factors of infection, it was observed that HBV infection was not related to parenteral exposure but only with sexual activity. In analogy, this fact could explain the low prevalence of $\mathrm{HCV}$, which is mainly spread by parenteral routes and very rarely sexually transmitted. Moreover, hepatitis $\mathrm{C}$ is associated with high risk lifestyles or particular demographic groups, being more prevalent in industrialized than in rural areas (Bisceglie 1998, Chadha et al. 1999).

Current hepatitis B vaccination programs do not attend all these riverine communities, probably due to the difficulty in accessing some villages during the dry season. Data from this work support the urgent hepatitis B massive vaccination of all children and adolescents living along the Purus and Acre rivers in order to prevent sexual, perinatal and early childhood HBV transmission. Moreover, since HBV chronic carrier state seems to be the most important reservoir for the propagation and maintenance of HDV, prophylactic measures against HBV will also control this serious form of hepatitis that showed alarming rates in this region.

\section{ACKNOWLEDGMENTS}

To Lucy Dalva Almeida da Silva for assistance in the hepatitis B virus subtyping assay, Flavio Ribeiro de Souza and Fernando S Dumas dos Santos for suppling photos and informations about the project "Revisitando a Amazônia de Carlos Chagas da Borracha a Bio- diversidade". To Clara Fumiko Tashibana Yoshida for revision of the manuscript.

\section{REFERENCES}

Arboleta M, Castilho MC, Fonseca JCF, Alburquerque BC, Saboia RC, Yoshida CFT 1995. Epidemiological aspects of hepatitis B and D virus infection in the northern region of Amazon Brazil. Trans R Soc Trop Med Hyg 89: 481-483.

Azevedo RA, Silva AE, Ferraz ML, Marcopito LF, Baruzzi RG 1996. Prevalence of serologic markers of hepatitis B and D viruses in children of the Caiabi and Txucarramae tribes from the Indian Reservation of Xingu central Brazil. Rev Soc Bras Med Trop 29: 431-439.

Bensabath G, Hadler SC, Pereira Soares MC, Fields H, Dias LB, Poper H, Maynard JE 1987a. Hepatitis Delta virus infection and Labrea hepatitis: prevalence and role in fulminat hepatitis in the Amazon Basin. JAMA 258: 479-483.

Bensabath G, Hadler SC, Soares MCP, Fields H, Maynard JE 1987b. Epidemiological and serologic studies of acute viral hepatitis in Brasil's Amazon Basin. Bull PAHO 21: 21-16.

Bisceglie AM 1998. Hepatitis C. Lancet 351: 351-355.

Casey JL, Niro GA, Engle RE, Vega A, Gomez H, McCarthy M, Watts DM, Hyams KC, Gerin JL 1996. Hepatitis B virus/hepatitis D virus (HBV/ HDV) coinfection in outbreaks of acute hepatitis in the Peruvian Amazon basin: the roles of HDV genotype III and HBV genotype F. J Infect Dis 174: 920926.

Chadha MS, Tungatkar SP, Arankalle VA 1999. Insignificant prevalence of antibodies to hepatitis $\mathrm{C}$ in a rural area of western Maharashtra. Indian J Gastroenterol 18: 22-23.

Coimbra Junior CE, Santos RV, Yoshida CF, Baptista ML, Flowers NM, do Valle AC 1996. Hepatitis B epidemiology and cultural practices in Ameridian populations of Amazonia: the Tupi-Monde and the Xavante from Brazil. Soc Sci Med 42: 1735-1743.

dos Santos FD, Thulen EV, Medeiros A, Reis R, Souza F 1996. Revisitando a Amazônia. Expedição aos Rios Negros e Branco Refaz Percurso de Carlos Chagas em 1913, Fiocruz, Rio de Janeiro, 112 pp.

Dusheiko G 1997. Hepatitis B: an overview. In M Rizzetto, RH Purcell, JL Gerin (eds), Viral Hepatitis and Liver Disease, Verme G Edizioni Minerva Medica, Torino, p. 57-66.

Fay OH 1990. Hepatitis B in Latin America: epidemiological patterns and eradication strategy. The Latin American Regional Study Group. Vaccine 8: S100106.

Fay OH, Hadler SC, Maynard JE, Pinheiro FP 1985. Hepatitis in the Americas. Bull PAHO 6: 1.

Fonseca JCF, Simonetti SRR, Schatzmayr HG, Casteon MJ, Cesário ALO, Simonetti JR 1988. Prevalence of infection with hepatitis delta virus (HDV) among carriers of hepatitis B surface antigen in Amazonas State Brazil. Trans R Soc Trop Med Hyg 82: 469-471.

Gaspar AMC, Yoshida CFT 1987. Geographic distribution of HBsAg subtypes in Brazil. Mem Inst Oswaldo 
1128 Viral Hepatitis in Brazilian Amazon Basin - VS de Paula et al.

Cruz 86: 253-258.

Margolis HS, Alter MJ, Hadler SC 1991. Hepatitis B: evolving epidemiology and implications for control. Semin Liver Dis 11: 84-92.

Martinson FEA, Weigle KA, Royce RA, Weber DJ, Suchindran CM, Lemon SM 1998. Risk factors for horizontal transmission of hepatitis B virus in a rural district in Ghana. Am J epidemiol 147: 478-487.

Meng X-J 2000. Zoonotic and xenozoonotic risks of the hepatitis E virus. Infect Dis Review 2: 35-41.

Pang L, Alencar FE, Cerutti-C JR, Milhous WK, Andrade AL, Oliveira R, Kanessa-Thasan N, MaCarthy PO, Hoke JR CH 1995. Short report: hepatitis E infection in Brazilian Amazon. Am J Trop Med Hyg 52: 347-348.

Parana R, Cotrim HP, Cortey-Boennec ML, Trepo C, Lyra L 1997. Prevalence of hepatitis E virus IgG antibodies in patients from a referral unit of liver diseases in Salvador, Bahia, Brazil. Am J Trop Med Hyg 57: 60-61.

Pereira FE, Musso C, Lucas E de A 1993. Labrea-like hepatitis in Vitória, Espírito Santo state, Brazil: report of a case. Rev Soc Bras Med Trop 26: 237-242.

Piccinino F, Sagnelli E 1991. HDV infection in southern Italy: an epidemiological overview. Prog Clin Biol Rev 364: 33-39.

Pinho JRR, Sumita LM, Moreira RC, Souza VA, Saraceni CP, Oba IT, Carvalho CS Pannuti CS 1998. Duality of patterns in hepatitis a epidemiology: A study involving two socioeconomically distinct populations in Campinas, São Paulo State, Brazil. Rev Inst Med Trop S Paulo 40: 105-106.

Skidmore SJ 1997. Tropical aspects of viral hepatitis E. Trans $R$ Soc Trop Med Hyg 91:125-126.

Soares MC, Menezes RC, Martins SJ, Bensabath G 1994.
Epidemiology of hepatitis B, C and D viruses among indigenous Parakana tribe in the Eastern Brazilian Amazon Region. Bol Oficina Sanit Panam 177: 124135.

Souto FJ, Fontes CJ, Gaspar AMC 1998. Outbreak of hepatitis B virus in recent arrivals to the Brazilian Amazon. J Med Virol 56: 4.

Souto FJ, Fontes CJ, Gaspar AM, Parana R, Lyra LG 1996. Concomitant high prevalence of hepatitis C virus antibodies and hepatitis $B$ virus markers in a small village of the Amazon Region Mato Grosso State Brazil. Rev Inst Med Trop São Paulo 38: 221223.

Souto FJ, Fontes CJ, Martelli CM, Turchi MD, Martins RM, Andrade AL 1999. Hepatitis C virus prevalence among an immigrant community to the southern Amazon Brazil. Mem Inst Oswaldo Cruz 94: 719-723.

Souto FJ, Fontes CJ, ParanaR Lyra LG 1997. Short report: further evidence for hepatitis $\mathrm{E}$ in the Brazilian Amazon. Am J Trop Med Hyg 57: 149-150.

Vitral CL, Gaspar AMC, Yoshida CFT 1991. Two competitive enzyme immunoassays for the detection of IgG class antibodies to hepatitis A antigen. Rev Soc Bras Med Trop 24: 79-85.

Vitral CL, Yoshida CFT, Lemos ER, Teixeira CS, Gaspar AM.C 1998a. Age-specific prevalence of antibodies to hepatitis A in children and adolescents from Rio de Janeiro, Brazil 1978 and 1995. Relationship of prevalence to environmental factors. Mem Inst Oswaldo Cruz 93: 1-5.

Vitral CL, Yoshida CFT, Lemos ER, Teixeira CS, Gaspar AMC 1998b. Seroprevalence of hepatitis A in health care students from a public university of Rio de Janeiro, Brazil. Rev Microbiol 29149-151. 